\title{
Шумская О.А. \\ Системно-деятельностный подход как механизм реализации ФГОС нового поколения
}

МОУ «СОШ №1» города Валуйки Белгородской области (Россия, Валуйки)

doi:10.18411/spc-22-03-2018-10

idsp: 000001:spc-22-03-2018-10

Постановка проблемы и ее актуальность:

Федеральный Государственный Образовательный стандарт выдвинул новые требования к результатам освоения основных образовательных программ, т.к. российские школьники показывают значительно более низкие результаты при выполнении заданий, связанных с использованием научных методов наблюдения, классификации, сравнения, формулирования гипотез и выводов, планирования эксперимента, связанных с проведением исследования, поэтому в настоящий момент времени необходимыми становятся не сами знания, а знания о том, как и где их добывать, применять и интерпретировать.

Желая сместить акцент в образовании , мы приходим к выводу, что надо менять характер учебного процесса и способы деятельности учащихся. Поэтому и появилась потребность введения системно-деятельностного метода обучения. [1; 16]

Содержательная часть:

Понятие системно-деятельностного подхода существует с 1985 г. Проблемы деятельности разрабатывались в разных гуманитарных дисциплинах, но прежде всего в философии и психологии. Деятельностный подход к жизни вообще и к обучению в частности является значительным достижением психологии. Известный психолог Леонтьев говорил, что человеческая жизнь - это «система сменяющих друг друга деятельностей». Процесс обучения как передача информации от учителя к ученику, считают психологи, противоречит самой природе человека - только через собственную деятельность каждый познает мир.

Системно-деятельностный подход - лежит в основе стандартов нового поколения. Которые ориентированы не на само содержание образования, хотя с ним связаны, а на результаты образования, результаты деятельности и требования к этим результатам. В системно-деятельностном подходе категория "деятельности" занимает одно из ключевых мест.[2;36]

Деятельность это всегда целеустремлённая система, система, нацеленная на результат. При определении результатов необходимо учитывать психологовозрастные, индивидуальные особенности развития личности ребёнка и присущи этим особенностям формы деятельности.

Школа выполняет заказ, сформулированный в стандартах. Стандарты социальная конвенциональная норма, общественный договор между семьей, обществом и государством: семья предъявляет требования к созданию условий для успешности личностной, социальной, профессиональной; общество - к безопасности и здоровью, свободе и ответственности, социальной справедливости, благосостоянию; государство - к сохранению национального единства, безопасности, развитию человеческого потенциала, конкурентоспособности. Сейчас задача системы образования состоит не в передаче объёма знаний, а в том, чтобы научить учиться.

Каждый раз, составляя проект очередного урока, учитель задает себе одни и те же вопросы:

1. Как организовать современный урок с точки зрения системнодеятельностного подхода?

2. Как сформулировать цели урока с позиций планируемых результатов образования и обеспечить их достижение? 
3. Какой учебный материал отобрать и как подвергнуть его дидактической обработке?

4. Какие методы и средства обучения выбрать?

5. Как организовать собственную деятельность и деятельность учеников?

6. Как обеспечить рациональное сочетание всех этих компонентов?

При подготовке к очередному уроку, нужно помнить, что основная идея системно-деятельностного подхода состоит в том, что новые знания не даются в готовом виде. Дети должны «открывать» их сами в процессе самостоятельной исследовательской деятельности. Задача учителя при введении нового материала заключается не в том, чтобы все наглядно и доступно объяснить, показать и рассказать. Учитель должен организовать исследовательскую работу детей, чтобы они сами додумались до решения проблемы урока и сами объяснили, как надо действовать в новых условиях.

Функция учителя заключается не в обучении, а в сопровождении учебного процесса: подготовка дидактического материала для работы, организация различных форм сотрудничества, активное участие в обсуждении результатов деятельности учащихся через наводящие вопросы, создание условий для самоконтроля и самооценки. Результаты занятий допускают неокончательное решение главной проблемы, что побуждает детей к поиску возможностей других решений, к развитию ситуации на новом уровне.[3;94]

Реализация деятельностного подхода в практическом преподавании обеспечивается следующей системой дидактических принципов, остановлюсь на некоторых:

1) Принцип деятельностизаключается в том, что ученик, получает знания не в готовом виде, а добывает их сам, что способствует формированию его общекультурных и деятельностных способностей, общеучебных умений. Самое главное, ученикам становится интересно содержание урока, интересным становятся результаты собственной деятельности.

2) Принцип непрерывностиозначает преемственность между всеми ступенями и этапами обучения на уровне технологии, содержания и методик с учетом возрастных психологических особенностей развития детей

3) Принцип психологической комфортностипредполагает снятие всех стрессообразующих факторов учебного процесса, создание в школе и на уроках доброжелательной атмосферы, ориентированной на реализацию идей педагогики сотрудничества, развитие диалоговых форм общения (это не сентиментальные отношения, не атмосфера вседозволенности, как считают некоторые учителя, а деловые доброжелательные отношения, основанные на уважении личности ученика и учителя; воспитание веры в себя, в свои возможности) [5;5-12]

В системно - деятельностном подходе существуют разные типологии уроков, типологии разных авторов. В своей практической деятельности можно использовать следующие типы уроков: урок «открытие нового знания»; урок формирования ЗУНов (урок парной работы); уроки развивающего контроля, уроки общения). На всех этих уроках происходит формирование предметных умений и навыков, но кроме этого они позволяют формировать и универсальные учебные действия.

Урок «открытия новых знаний»: на этих уроках формируется умение анализировать результаты своей деятельности, выявлять места и причины затруднений, умение ставить цели урока и подводить итог. На уроках школьники учатся решать нестандартные задачи, комбинировать имеющиеся знания, выдвигать гипотезы, искать пути решения проблем. Они наблюдают, сравнивают, анализируют, делают выводы и обобщения. В результате происходит творческое овладение знаниями, умениями, навыками и развитие мыслительных процессов, коммуникативных действий, познавательной активности. 
Урок парной работы (формирование ЗУНов, коррекция пробелов): формируются навыки самостоятельной деятельности, навыки парной работы (школьники учатся управлению поведением партнера, планированию самостоятельной и совместной деятельности, осуществлять взаимоконтроль и самоконтроль). Отдельные ученики ставятся в положение учителя, появляется реальная возможность оказания реальной помощи друг другу. Эта форма порождает взаимную ответственность, внимательность, формирует интерес к работе товарища, через нее можно совместно изучать новый материал, отрабатывать алгоритмы, тренировать друг друга, проверять, обучать, обсуждать.

Урок общение (теоретический опрос по теме, также включены небольшие практические задания): формируются умение организовать учебное взаимодействие в группе, сотрудничество со сверстниками, умение слушать и слышать, давать оценку своим результатам и результатом товарищей. В процессе таких уроков формируется критическое мышление, а также очень важная способность мобилизовать в определенной ситуации приобретенные знания и опыт.[4;17]

Структура урока с позиций системно - деятельностного подхода состоит в следующем:

- учитель создает проблемную ситуацию;

- ученик принимает проблемную ситуацию;

- вместе выявляют проблему;

- учитель управляет поисковой деятельностью;

- ученик осуществляет самостоятельный поиск;

- обсуждение результатов.

Хочется закончить свое выступление словами немецкого педагога 19 в. Адольфа Дистерверга «Настоящий учитель показывает своему ученику не готовое здание, над которым положены тысячелетия труда, он ведет его к разрабатыванию строительного материала, возводит здание с ним вместе, учит его строительству». Учитель должен слышать и понимать детей, а не навязывать свое мнение.

$$
* * *
$$

1. Концепция федеральных государственных образовательных стандартов общего образования: проект / [Рос. акад. образования]; под ред. А.М. Кондакова, А.А. Кузнецова. -М.: Просвещение,2008. -С. 16. -(Стандарты второго поколения).

2. Системно-деятельностный подход как механизм реализации ФГОС нового поколения: сб. практич. материалов /сост. О.И. Чистикова. - Архангельск: АО ИППК РО, 2012. -36с

3. Подгорная А.К.О системно- деятельностном подходе в подготовке учителя к работе по новому государственному образовательному стандарту начального общего образования (ФГОС НОO) / А. К. Подгорная // Администратор образования (Ов Д). -2011. -No 23. -С. 93-95.

4. Серебрякова Л.А.Системно- деятельностный подход как условие формирования ключевых компетентностей школьников / Л. А. Серебрякова // Методист. -2011. -No 2. -С. 14-17. -Библиогр.: c. 17.

5. Вагнер И.В.Воспитательный компонент федеральных государственных образовательных стандартов: подходы к развитию и реализации / И. В. Вагнер // Соц. педагогика. -2012. -No 2. -С. $5-12$. 